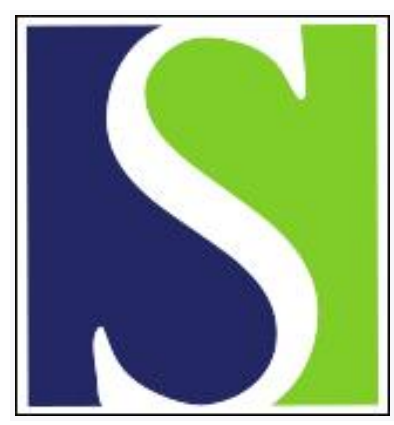

Scand J Work Environ Health 1978;4(1):39-46

https://doi.org/10.5271/sjweh.2765

Issue date: 1978

Diminished dynamic performance capacity of back and abdominal muscles in concrete reinforcement workers.

by Nummi J, Järvinen T, Stambej U, Wickstrom G

Key terms: abdominal muscle; back; back muscle; concrete reinforcement work; concrete reinforcement worker; diminished dynamic performance capacity; dynamic performance capacity; dynamic test; performance capacity; straight abdominal muscle

This article in PubMed: www.ncbi.nlm.nih.gov/pubmed/149367 
Scand. j. work environ. \& health 4 (1978): suppl. 1, 39-46

\title{
Diminished dynamic performance capacity of back and abdominal muscles in concrete reinforcement workers
}

\author{
by JUHANI NUMMI, M.D., ${ }^{1}$ TUULIKKI JÄRVINEN, ${ }^{1}$ ULLA STAMBEJ ${ }^{1}$ and \\ GUSTAV WICKSTRÖM, M.D.2
}

\begin{abstract}
NUMMI, J., JÄRVINEN, T., STAMBEJ, U. and WICKSTRÖM, G. Diminished dynamic performance capacity of back and abdominal muscles in concrete reinforcement workers. Scand. j. work environ. \& health 4 (1978): suppl. 1, 39-46. The dynamic performance capacity of back and straight abdominal muscles was clinically examined in 295 male Finnish concrete reinforcement workers aged 19 to 64 years and engaged in heavy physical work including prolonged stooping. In $24 \%$ of the men both back and straight abdominal muscle performance capacity was reduced, in $18 \%$ only the capacity of the straight abdominal muscles, and in $4 \%$ only the performance of the back muscle. The prevalence of diminished trunk muscle performance capacity increased rapidly with age. Diminished back muscle performance capacity was associated with a history of sciatica $\left(\chi^{2}=16.9, \mathrm{p}<0.001\right)$ and diminished performance capacity of the straight abdominal muscles with a history of lumbago $\left(\chi^{2}=5.9, \mathrm{p}<0.02\right)$ after adjustment for age. Diminished back muscle performance was associated with backache $\left(\chi^{2}=16.9, \mathrm{p}<0.001\right)$ and sharp pain in the back $\left(\chi^{2}=4.5, \mathrm{p}<0.05\right)$ during an ordinary workday, as was also diminished performance of the straight abdominal muscles $\left(\chi^{2}=23.8, \mathrm{p}<0.001\right.$ and $\chi^{2}=7.3, \mathrm{p}<0.01$, respectively). No association between length of exposure to the back loads in reinforcement work and the prevalence of diminished trunk muscle performance capacity could be established.
\end{abstract}

Key words: back muscle, concrete reinforcement worker, dynamic test, straight abdominal muscles.

The relationship between trunk muscle strength and low-back pain is still unclear. Persons with diminished muscle strength have been found to be especially prone to low-back pain. On the other hand, diminished trunk muscle strength has been found as a residual sign of previous back pain syndromes.

In this article we have presented the prevalence of diminished trunk muscle performance capacity in a group of skilled construction workers. We have also exam-

1 Institute of Occupational Health, Helsinki, Finland.

2 Turku Regional Institute of Occupational Health, Turku, Finland. ined the relationship between diminished trunk muscle performance and a history of low-back pain syndromes, as well as reported present back symptoms.

\section{MATERIAL AND METHODS}

The group studied comprised 295 male Finnish concrete reinforcement workers, aged 19-64 years. A detailed characterization of the group has been given elsewhere (22). An ergonomic analysis of reinforcement work showed the frequency and duration of the stooping postures to be extraordinarily common in this occupation 


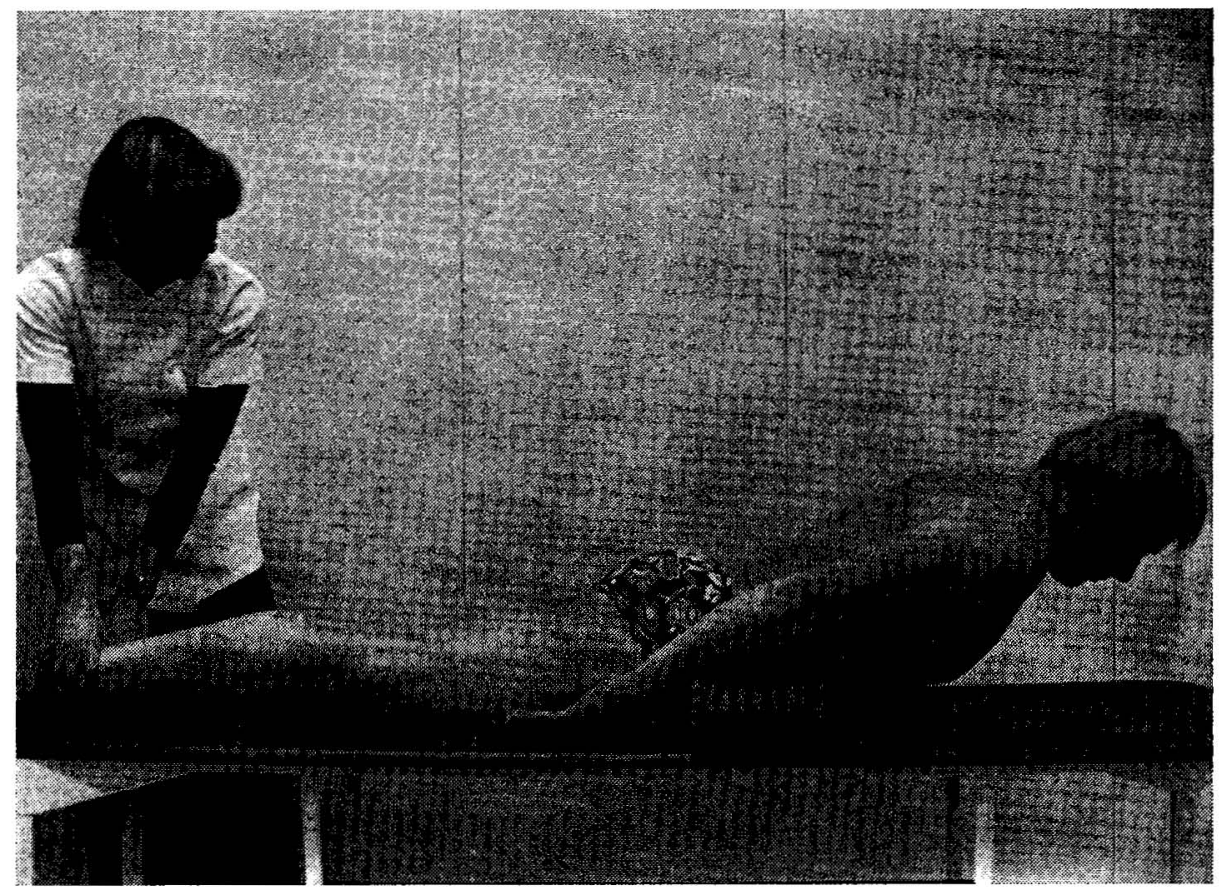

Fig. 1. Method for determining dynamic back muscle performance capacity. The position of the subject illustrates the minimal degree of extension for approved performance.

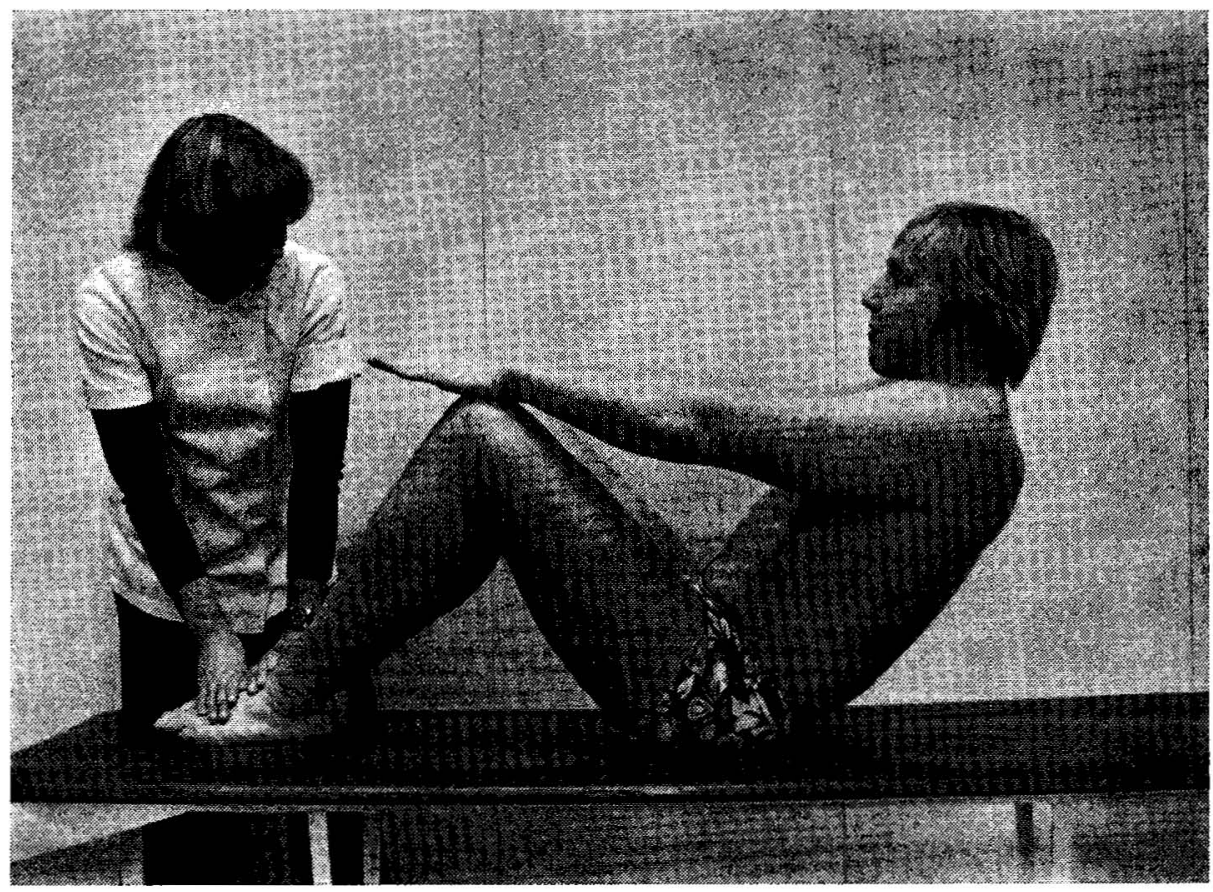

Fig. 2. Method for determining dynamic straight abdominal muscle performance capacity. The position of the subject illustrates the minimal degree of flexion for approved performance. 
Table 1. Prevalence $(\%)$ of diminished dynamic performance capacity of back muscle and straight abdominal muscles by age.

\begin{tabular}{|c|c|c|c|c|c|c|}
\hline \multirow{2}{*}{$\begin{array}{l}\text { Diminished } \\
\text { dynamic } \\
\text { performance } \\
\text { capacity }\end{array}$} & \multicolumn{6}{|c|}{ Age (years) } \\
\hline & $\begin{array}{l}15-24 \\
(N=15)\end{array}$ & $N \stackrel{25-34}{=} 77-78)$ & 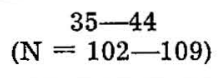 & $(\mathrm{N} \stackrel{45-54}{=} 60-62)(\mathrm{N}$ & $\mathrm{N} \stackrel{55-64}{=28-30)(\mathrm{N}}$ & $\begin{array}{l}15-64 \\
=282-294)\end{array}$ \\
\hline \multirow{2}{*}{$\begin{array}{l}\text { Back muscle } \\
\text { Straight abdominal } \\
\text { muscles }\end{array}$} & 7 & 18 & 24 & 40 & 54 & 27 \\
\hline & 13 & 26 & 45 & 47 & 83 & 43 \\
\hline
\end{tabular}

(20). The method used to obtain the history of back diseases and symptoms has been presented by Wickström et al. (22).

The dynamic trunk muscle performance was clinically examined by an experienced and specially trained physiotherapist. Back muscle performance capacity (M. erector spinae) was examined while the reinforcement worker lay on his stomach with an approximately 10 -cm high support under his stomach to prevent sudden hyperlordosis. The worker kept his arms fixed at his sides. While the examiner held the feet of the worker on the table, he slowly bent his trunk backward so that the thorax rose $10-15 \mathrm{~cm}$ from the table (fig. 1). Back muscle performance was considered normal if the worker was able to repeat the movement seven times or more, diminished if he repeated it only three to six times, and strongly diminished if the repetition was less than three times.

The dynamic performance capacity of the straight abdominal muscles was tested while the concrete reinforcement worker lay on his back with his knees flexed. His arms were free and directed towards the knees. The examiner held the man's feet on the table. If the reinforcement worker rose to the sitting position (fig. 2) smoothly, without jerks, seven times or more, his muscle performance was considered normal; if he rose only three to six times, his performance capacity was classified as diminished; and, if he rose less than three times, it was considered strongly diminished. Jerking movements always led to a classification of strongly diminished muscle performance capacity.

Due to subjective discomfort the testing of back muscle performance was omitted from the clinical examination in 13 cases and the test for abdominal muscle perform- ance in 1 case. The symptom questionnaire was expanded in the beginning of the study, and therefore present back symptoms were recorded in detail for only the last 223 men examined (22).

In the graphical presentation of the results the observed prevalences were smoothed by the calculation of 15-year moving age ranges for the prevalence estimates.

\section{RESULTS}

The dynamic back muscle performance capacity was classified as normal in $73 \%$ of the concrete reinforcement workers, moderately diminished in $24 \%$, and strongly diminished in $3 \%$. The dynamic performance capacity of the straight abdominal muscles was considered normal in $57 \%$, moderately diminished in $29 \%$, and strongly diminished in $14 \%$ of the men.

When the findings of diminished back and abdominal muscle performance were compared, a reduction of back muscle capacity only was found in $4 \%$ of the workers, a reduction of abdominal muscle capacity only in $18 \%$, and a reduction of both back and abdominal muscle capacity in $24 \%$. In $54 \%$ of the workers both back and abdominal muscle performance capacity were normal.

The prevalence of diminished back and abdominal muscle performance increased with age (table 1). According to the criteria employed, only $13 \%$ of the men showed a reduction of either back or abdominal muscle performance at the age 15 to 24 years, while at the age 55 to 64 years the proportion was the same for men not showing diminished trunk muscle performance capacity. The age dependence of 
reduced dynamic performance in back muscles alone, straight abdominal muscles alone, and in back and abdominal muscles simultaneously appears in fig. 3.

The data on diminished trunk muscle performance were analyzed for a possible effect of reinforcement work by an ageadjusted comparison of workers with short and long employment times in reinforcement work. No statistically significant results were obtained. Neither was any clear

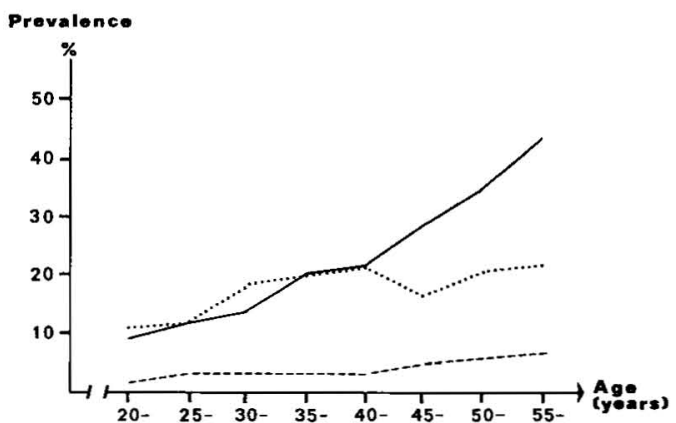

Fig. 3. Smoothed prevalence estimates for diminished dynamic strength of back muscle alone (-- ), straight abdominal muscles alone $(.$.$) and back and straight abdominal muscles$ together (-) by age.

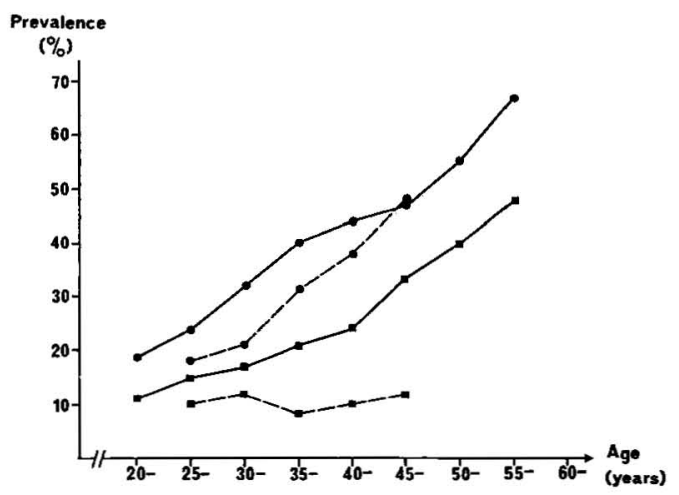

Fig. 4. Smoothed prevalence estimates for diminished dynamic performance capacity of back muscle in reinforcement workers (घ-D) and computer technicians (口- - - $\mathbf{0})$ and for diminished dynamic performance capacity of straight abdominal muscles in reinforcement workers (- $\longrightarrow$ ) and computer technicians (- - $-\bullet$ ) by age. indication of an occupational effect on the prevalence of diminished trunk muscle capacity found when the reinforcement workers were compared to another occupational group often working in awkward postures, i.e., computer technicians (fig. 4).

Of the men with diminished back muscle performance capacity, $47 \%$ reported a history of lumbago, and $59 \%$ a history of sciatica (table 2). The corresponding figures for the men with normal back muscle capacity were $28 \%$ and $36 \%$, respectively. Also after age adjustment the association between diminished back muscle capacity and a history of sciatica was significant $\left(\chi^{2}=16.9, \mathrm{p}<0.001\right)$

In the men with diminished performance of the straight abdominal muscles a history of lumbago $(44 \%)$ and a history of sciatica $(52 \%)$ were more common than in the men with normal abdominal muscle capacity $(24 \%$ and $34 \%$, respectively). After age adjustment diminished abdominal muscle capacity was still associated with a history of lumbago $\left(\chi^{2}=5.9, \mathrm{p}<\right.$ 0.02).

The incidence of fatigue, stiffness, ache, and sharp pain in the back during an ordinary workday was clarified in an interview on orthopedic symptoms. Table 3 shows reported back symptoms compared to the findings of diminished back and abdominal muscle performance capacity. Men with diminished back muscle performance more commonly reported ache $\left(\chi^{2}=16.9, \mathrm{p}<0.001\right)$ and sharp pain $\left(\chi^{2}=\right.$ $4.5, \mathrm{p}<0.05)$ in the back than men with normal muscle performance. The same two back symptoms were also related to diminished performance capacity of the straight abdominal muscles $\left(\chi^{2}=23.8, \mathrm{p}<\right.$ 0.001 and $\chi^{2}=7.3, \mathrm{p}<0.01$, respectively).

Because working in bent-double postures is very common in concrete reinforcement work, the workers were interviewed on back symptoms as they ibent down, while in the bent-double position, and as they straightened up. The back symptoms in reinforcement workers with and without diminished trunk muscle performance capacity are presented in table 4 . Symptoms on bending down were related to the reduction of both back $\left(\chi^{2}=5.2, \mathrm{p}<\right.$ $0.01)$ and abdominal $\left(\chi^{2}=11.9, p<0.001\right)$ muscle performance capacity. 
Table 2. Prevalence $(\%)$ of a history of lumbago and/or sciatica in concrete reinforcement workers with and without diminished dynamic trunk muscle performance capacity $(\mathrm{N}=295)$.

\begin{tabular}{|c|c|c|c|c|}
\hline \multirow{2}{*}{$\begin{array}{l}\text { Previous } \\
\text { back } \\
\text { syndromes }\end{array}$} & \multicolumn{2}{|c|}{$\begin{array}{c}\text { Dynamic performance } \\
\text { capacity of back } \\
\text { muscle }\end{array}$} & \multicolumn{2}{|c|}{$\begin{array}{l}\text { Dynamic performance } \\
\text { capacity of straight } \\
\text { abdominal muscles }\end{array}$} \\
\hline & $\begin{array}{l}\text { Dimin- } \\
\text { ished } \\
(\mathrm{N}=77)\end{array}$ & $\begin{array}{l}\text { Not dimin- } \\
\text { ished } \\
(\mathrm{N}=205)\end{array}$ & $\begin{array}{l}\text { Dimin- } \\
\text { ished } \\
(\mathrm{N}=125)\end{array}$ & $\begin{array}{l}\text { Not dimin- } \\
\text { ished } \\
(\mathrm{N}=169)\end{array}$ \\
\hline \multicolumn{5}{|c|}{ Neither lumbago } \\
\hline nor sciatica & 30 & 54 & 34 & 59 \\
\hline Only lumbago & 10 & 10 & 14 & 7 \\
\hline Onily sciatica & 23 & 18 & 22 & 17 \\
\hline \multicolumn{5}{|l|}{ Both lumbago } \\
\hline & & & & \\
\hline Total & 100 & 100 & 100 & 100 \\
\hline
\end{tabular}

Table 3. Incidence $(\%)$ of present baok symptoms in concrete reinforcement workers with and without diminished dynamic trunk muscle performanoe capacity $(\mathrm{N}=213-223)$.

\begin{tabular}{|c|c|c|c|c|}
\hline \multirow{2}{*}{$\begin{array}{l}\text { Present } \\
\text { back } \\
\text { symptoms }\end{array}$} & \multicolumn{2}{|c|}{$\begin{array}{c}\text { Dynamic performance } \\
\text { capacity of back } \\
\text { muscle }\end{array}$} & \multicolumn{2}{|c|}{$\begin{array}{l}\text { Dynamic performance } \\
\text { capacity of straight } \\
\text { abdominal muscles }\end{array}$} \\
\hline & $\begin{array}{l}\text { Dimin- } \\
\text { ished } \\
(\mathrm{N}=52)\end{array}$ & $\begin{array}{l}\text { Not dimin- } \\
\text { ished } \\
(\mathrm{N}=161)\end{array}$ & $\begin{array}{l}\text { Dimin- } \\
\text { ished } \\
(\mathrm{N}=91)\end{array}$ & $\begin{array}{l}\text { Not dimin- } \\
\text { ished } \\
(\mathrm{N}=132)\end{array}$ \\
\hline Fatigue & 40 & 48 & 49 & 45 \\
\hline Stiffness & 44 & 40 & 45 & 38 \\
\hline Ache & 75 & 42 & 70 & 37 \\
\hline Sharp pain & 21 & 10 & 21 & 8 \\
\hline
\end{tabular}

Table 4. Incidence $(\%)$ of back symptoms, while stooping, in concrete reinforcement workers with and without diminished dynamic trunk muscle performance capacity $(\mathrm{N}=213-223)$.

\begin{tabular}{|c|c|c|c|c|}
\hline \multirow{2}{*}{$\begin{array}{l}\text { Back symptoms } \\
\text { in different } \\
\text { phases of } \\
\text { stooping }\end{array}$} & \multicolumn{2}{|c|}{$\begin{array}{c}\text { Dynamic performance } \\
\text { capacity of back } \\
\text { muscle }\end{array}$} & \multicolumn{2}{|c|}{$\begin{array}{l}\text { Dynamic performance } \\
\text { capacity of straight } \\
\text { abdominal muscles }\end{array}$} \\
\hline & $\begin{array}{c}\text { Dimin- } \\
\text { ished } \\
(\mathrm{N}=51-52)\end{array}$ & $\begin{array}{c}\text { Not dimin- } \\
\text { ished } \\
(\mathrm{N}=161)\end{array}$ & $\begin{array}{c}\text { Dimin- } \\
\text { ished } \\
(\mathrm{N}=90-91)\end{array}$ & $\begin{array}{l}\text { Not dimin- } \\
\text { ished } \\
(\mathrm{N}==131-132)\end{array}$ \\
\hline $\begin{array}{l}\text { Bending down } \\
\text { In the bent-double }\end{array}$ & 54 & 36 & 55 & 32 \\
\hline posture & 78 & 70 & 80 & 67 \\
\hline Straightening up & 63 & 62 & 68 & 58 \\
\hline
\end{tabular}

\section{DISCUSSION}

Both the maintenance of the upright posture and the regulation of flexion and extension of the spine primarily depend on the erector spinae muscle and the abdominal muscles. The erector spinae muscle functions as the stabilizer of the whole vertebral column (6).

Flexion is initiated by the abdominal muscles and controlled by the back muscle. When a person leans forward $45^{\circ}$, 
the load on the erector spinae muscle is at its height. When bending further forward the burden of the upper part of the body is more and more taken over by passive tension so that the back muscle, when followed electromyographically, is nearly silent at $90^{\circ}(7)$. The erector spinae muscle endures $25 \%$ of the maximal extension strength for 10 to $20 \mathrm{~min}$ (13), and $15 \%$ can be maintained "indefinitely" (9, $17)$.

The methods used to measure the maximal strength of the back and abdominal muscles included clinical orthopedic evaluation, use of mechanical devices, and electromyography $(4,7,11,15,16,19)$.

Comparing the results from four differents tests for back muscle strength, Pedersen and Staffeldt (15) found that the results from three tests for maximal muscular strength in $1-3$ performances correlated well with each other. The test for endurance time, in principle similar to the tests used by Okada et al. (13), gave different results.

The method we used in our study measured dynamic performance capacity in a manner similar to Pedersen's and Staffeldt's test III. We chose the dynamic tests for trunk muscle strength determination because they probably measure low-back disability more accurately than the tests for isometric muscle strength $(1,11,18,21)$. The classification we used is based on clinical experience.

Diminished muscle strength may be due to muscular disease, such as myasthenia, to diseases of the nervous system, such as diabetic polyneuropathy, or to disuse of the muscles. As the examined group consisted of active workers from a strenuous occupation, the possibility of grave muscular or nervous diseases was excluded. Neither were any significant neurological signs not attributable to spinal degeneration found in the clinical examination. Due to the demands of reinforcement work the trunk muscles are probably exercised to a considerable extent in reinforcement workers. Diminished back muscle performance capacity is thus supposedly mainly due to peripheral nerve root lesions, but acute, minor trauma or pain causing a reversible reduction of trunk muscle performance capacity may also have been responsible for a part of the findings.

The age dependence of muscle strength has been investigated by Asmussen and Heebøll-Nielsen (3) in men $175 \mathrm{~cm}$ tall and representing various occupations. Back muscle strength was at its best $(91 \mathrm{kp}$, i.e., $890 \mathrm{~N}$ ) in the age group $30-39$ years and was diminished by $15 \%$ in the group 60 69 years. Abdominal muscle strength showed a peak value at a corresponding age $(67 \mathrm{kp}$, i.e., $660 \mathrm{~N})$ and fell by $16 \%$ by $60-69$ years. In forestry workers back muscle strength was reduced by $25 \%$ from age $20-29$ years to $60-69$ years, while abdominal muscle strength showed only a $10 \%$ reduction over the same age period (2).

The prevalence of diminished trunk muscle performance capacity among concrete reinforcement workers can be compared to findings among computer technicians, investigated by identioal methods in another cross-sectional study (12). The computer technicians (104 Finnish males, aged 20-54 years) often worked in awkwand postures especially demanding for the back and the knees. The age-adjusted prevalence of diminished back muscle capacity was 1.7 times higher among reinforcement workers, but the corresponding chi-square value of 3.1 was not statistically significant. The age-adjusted prevalence of the diminished capacity of the straight abdominal muscles was equally high in both groups (fig. 4).

Over the years considerable evidence has been presented in favor of an association between diminished trunk muscle strength and the occurrence of low-back pain, but the extent to which diminished trunk muscle strength may contribute to the occurrence of low-back pain and the degree to which episodes of low-back pain leads to a reduction of trunk muscle strength are questions still open for discussion and further study.

Kraus and Weber (10) found that the reduction of trunk muscle strength and flexibility below a certain level was associated with a high expectancy of back pain. Poulsen and Jørgensen (16) showed that maximal isometric strength should exceed two-thirds of a person's body weight to avoid fatigue and pain in the 
back from work in a forward-leaning position. Chaffin and Herrin (5) also found that workers with good "torso lifting strength," mainly a measure of back muscle strength, had significantly less lowback pain than weaker workers. On the other hand, Hirsch (8) considered muscular persons to be as susceptible to low-back pain as asthenics, and no evidence for an association between diminished trunk muscle strength and low-back pain has been found in two thorough investigations $(11,14)$.

Chronic low-back pain is frequently accompanied by generalized weakness of the trunk muscles (1). Up to $80 \%$ of patients with low-back pain may be classified as deficient in trunk muscle strength (10). A large prospective study (19) has shown that abdominal muscle weakness, found at the time of the low-back pain attack, often disappears with the remission of the episode of pain, but that it sometimes is left as a residual sign of previous low-back pain. Persons without experience of lowback pain had weakened abdominal muscles less often $(12 \%)$ than persons with a previous spell of low-back pain unaccompanied by an incapacity to work (26 $0 / 0$ ) and persons previously incapacitated because of low-back pain $(50 \%)$. Nachemson and Lindh (11), excluding cases of sciatica from their study, found no difference in the extensor or flexor strength of the trunk between persons without lowback pain and those incapacitated with back pain for less than a month. In persons incapacitated by low-back pain for more than a month they recorded a reduction of maximal isometric tension in the back and abdominal muscles; this condition was considered probably due to inactivity because of pain or fear of pain.

In the present study on concrete reinforcement workers the performance capacity of both back and straight abdominal muscles were found to be related to previous spells of both lumbago and sciatica. As the prevalences of diminished trunk muscle capacity and of a reported history of low-back pain syndromes both increase with age, the associations between these variables were analyzed after age adjustment. The association between diminished back muscle capacity and a history of sciatica was found to be clear, while the relation between diminished abdominal muscle capacity and a history of lumbago was weaker.

When specific back symptoms were compared to a reduction of trunk muscle performance, no relationship was found for the milder symptoms of "fatigue" and "stiffness, "while "ache" and "sharp pain" were associated with a reduction of both back and abdominal muscle performance capacity. Thus our assumption that the sensation of "fatigue" arises in the musculoligamentous structures from excessive demand on muscular contraction was not supported by our data.

There is a definite association between diminished itrunk muscle strength and lowback pain. This relation can be of three types:

1. Diminished trunk muscle strength causes low-back pain. Possible mechanisms: (a) pain arises in the muscular tissue itself or in stretched ligaments when demand on muscular contraction exceeds performance; (b) pain arises in the functional spinal unit (vertebral disc-nerve root-facet joint) from excessive mobility due to weakness of stabilizing trunk muscles or from abnormal patterns of movement in association with degenerative changes and weak muscles.

2. Low-back pain causes diminished trunk muscular strength. Possible mechanism: pain causes relative immobilization of the back structures and leads to diminished trunk muscle strength from lack of use.

3. Diminished trunk muscular strength and low-back pain are both effects of a common cause. Possible mechanism: degeneration of intervertebral discs and/or apophyseal joints causes damage to both the motor and the sensory roots of the spinal nerves.

In our opinion none of the these relationships can be ruled out at the present level of knowledge. Primarily we would consider the relation to start from degenerative spinal changes causing lesions of both the sensory and the motor nerve roots. As the back muscle is innervated from the corresponding spinal level, reduc- 
tion of back muscle strength may be due to lumbar disc degeneration, but the mechanism behind the reduction of abdominal muscle strength is less clear. Diminished trunk muscle strength may in turn contribute to further low-back morbidity as discussed by Alston et al. (1).

\section{REFERENCES}

1. ALSTON, W., CARLSON, K., FELDMAN D., GRIMM, $Z$. and GERONTINOS, E. A quantitative study of muscle factors in the chronic low back syndrome. J. am. geriatr. soc. 14 (1966): 10, 1041-1047.

2. ANDERSEN, L., VIK, T. and SKROBAKKACZYNSKI, J. Beskrivelse av enkelte biologiske karakteregenskaper som har betydning for yrkesutøvelsen hos nonske skogsarbeidere. Tidskr. skogbruk (1976): 2, 26.

3. ASMUSSEN, E. and HEEBØLL-NIELSEN, $\mathrm{K}$. Isometric muscle strength of adult men and women. (Communications from the testing and observation institute of the $\mathrm{Da}$ nish national association for infantile paralysis no. 11). Testing and Observation Institute of the Danish National Association for Infantile Paralysis, Hellerup 1961. $12 \mathrm{p}$.

4. CHAFFIN, D. Human strength capability and low-back pain. J. occup. med. 16 (1974): 4, 248-254.

5. CHAFFIN, D. and HERRIN, G. The effectiveness of pre-employment strength testing for manual materials handling jobs. In: Proceedings from 6th congress of the international ergonomics association, July 1116, 1976. University of Maryland, Md. 1976, pp. $17-23$.

6. DONISCH, E. and BASMAJIAN, J. Electromyography of deep back muscles in man. Am. j. anat. 133 (1972): 1, 25-36.

7. FLOYD, W. and SILVER, P. The function of the erectores spinae muscles in certain movements and postures in man. J. physiol. 129 (1955) 184-203.

8. HIRSCH, C. Low back pain etiology and pathogenesis. Appl. ther. 8 (1966) 857-862.

9. JÖRGENSEN, K. Back muscle strength and body weight as limiting factors for work in the standing slightly-stooped position (Communications from the testing and observation institute of the Danish national association for infantile paralysis no. 30). Testing and Observation Institute of the Danish National Association for Infantile Paralysis, Hellerup 1970. 9 p.

10. KRAUS, $H$. and WEBER, S. Back pain and tension syndromes in a sedentary profession. Arch. environ. health 4 (1962) 408414.

11. NACHEMSON, A. and LINDH, M. Measurement of abdominal and back muscle strength with and without low back pain. Scand. j. rehabil. med. 1 (1969) 60-65.

12. NUMMI, J., JÄRVINEN, T. and KOSKELA, A. Liikunnan merkitys selkä-ja polvivaivojen ehkäisyssä (Työolosuhteet no. 9). Institute of Occupational Health, Helsinki 1977. $24 \mathrm{p}$.

13. OKADA, M., KOGI, $K$. and ISHII, M. Enduring capacity of the erectores spinae muscles in static work. J. anthropol. soc. nippon 78 (1970): 2, 99-110.

14. PEDERSEN, O., PETERSEN, R. and STAFFELDT, E. Back pain and isometric back muscle strength of workers in a Danish factory. Scand. j. rehabil. med. 7 (1975) 125-128.

15. PEDERSEN, O. and STAFFELDT, E. The relationship between four tests of back muscle strength in untrained subjects. Scand. j. rehabil. med. 4 (1972) 175-181.

16. POULSEN, E. and JÖRGENSEN, $K$. Back muscle strength, lifting, and stooped working postures. Appl. ergon. 2 (1971): 3, 133137 .

17. ROHMERT, W. Ermittlung von Erhohungspausen für statische Arbeit des Menschen. Intern. 2. Angew. Physiol. 18 (1960) 123164.

18. ROWE, M. L. Disc surgery and chronic low-back pain. J. occup. med. 7 (1965): 15, 196-202.

19. ROWE, M. Low back pain in industry. $J$. occup. med. 11 (1969): 4, 161-169.

20. SAARI, J. and WICKSTRÖM, G. Load on back in concrete reinforcement work. Scand. j. work environ. \& health 4 (1978): suppl. 1, 13-19.

21. TROUP, D. Lumbar spinal disability in dockworkers. Presented at the Seminar on low-back problems and work, Institute of Occupational Health, Helsinki, 1976. 5 p.

22. WICKSTROMM, G., HÄNNINEN, K., LEHTINEN, M. and RIIHIMÄKI, R. Previous back syndromes and present back symptoms in concrete reinforcement workers. Scand. j. work environ. \& health 4 (1978): suppl. 1, 20-28. 